\section{Reconstruction of Internal Ca- rotid Artery Stenosis in Patients Older than 70 Years under Local Anaesthesia}

\author{
Alina Fazlić ${ }^{1,3 *}$, Muhamed Zuko ${ }^{2,3}$, Elma Sokić-Begović ${ }^{3}$, Sanela \\ Šuškić ${ }^{3}$ and Amer Šuškić ${ }^{3}$ \\ ${ }^{1}$ Department of Anesthesiology, Public Institution, Hospital of Travnik, Bosnia \\ and Herzegovina, Balkans
}

2Public Institution, Psychiatric Hospital of the Canton of Sarajevo "Jagomir", Bosnia and Herzegovina, Balkans

${ }^{3}$ Pharmacy and Medical Faculties, Universitat of Travnik, Bosnia and Herzegovina, Balkans

\begin{abstract}
Patients older than 70 years old with stenosis of the internal carotid artery, followed by the problems in the function of other systems in the body, are becoming more common patients in our clinic. In this work, we have a case report of a patient with Carotid Artery Stenosis (CAS) (Stenosis ACC et $\mathrm{ACl}$, left $\mathrm{ACl}$ stenosis over $80 \%$,right $\mathrm{ACl}$ stenosis $70 \%$, Atherosclerosis ACC et $\mathrm{ACl}$, Insuff. Verthebrobasilaris) solve Carotid Endarterectomy (CEA) under local anesthesia. Diseases present in a patient, aged 81 years, are: Status post ICV per emboliam /lacunaris/ am X; Hypertensio arterialis gr II; Cor atheroscleroticum chronicum compensatum; Arrythmia absoluta cordis; COPB; Status post infiltratio pulmonum lat.dex. am II; DM typ II; Cholecystitis chronica calculosa.
\end{abstract}

Keywords: High risic patient; Internal carotid arthery; Local anesthesia; Stenosis

\section{Introducion}

Surgery of the large blood vessels is a major challenge for anesthesia. The dramatic disruption physiology builds on the existing

*Corresponding author: Alina Fazlić, Department of Anesthesiology, Public Institution, Hospital of Travnik, Bosnia and Herzegovina, Balkans, Tel: 0038761 614 423; Email: alina.fazlic@gmail.com

Citation: Fazlić A, Zuko M, Sokić-Begović E, Šuškić S, Šuškić A (2019) Reconstruction of Internal Carotid Artery Stenosis in Patients Older than 70 Years under Local Anaesthesia. J Anesth Clin Care 6: 44.

Received: November 8, 2019; Accepted: December 4, 2019; Published: December 11, 2019

Copyright: () 2019 Fazlic A, et al. This is an open-access article distributed under the terms of the Creative Commons Attribution License, which permits unrestricted use, distribution, and reproduction in any medium, provided the original author and source are credited. complex patient conditions. Vascular surgery requires a temporary interruption of the flow of arterial blood resulting in tissue ischemia, possible organ damage and production anaerobic metabolites [1]. A significant health problem, in the world and in our country, represents cerebrovaskularba disease that is on the top of the causes of death $[1,2]$. Over $85 \%$ of strokes are caused by thromboembolic complications in the heart and/or blood vessels. $90 \%$ of ischemia related to the current field of carotid artery. All contributing risk factors: arterial hypertension, diabetes mellitus, ages (people older than 55 years are more prone to diseases of blood vessels), cigarette smoking, genetic predisposition, hyperlipidemia/dislipoproteinemia [3]. Indications for treatment of patients with carotid artery stenosis are set on the basis of several factors: neurological symptoms and the degree of carotid stenosis, comorbidity and high riskiness of the patient and local anatomical features stenosis. As the choice of surgical treatment, CEA has proven to be a safe and effective method of reducing the risk of stroke in patients with a high percentage of stenosis $[3,4]$. Becouse of the bad general condition of patients, who are increasingly appearing in our clinic, more in practice perform CEA under local anesthesia. The results are very good, the patients during surgery and postoperative care, are less exposed to complications.

\section{Case Report}

81 year old patient, a man, coming to our clinic with a referral from a health center under suspicion of cholecystitis. After laboratory results and $\mathrm{EHO}$ abdomen, shows us that it is a chronic inflammation of the gallbladder with solitary calculi size of about $15 \mathrm{~mm}$. The medical documentation shows that the patient has CVI before three month. Color Doppler vascular neck showed: Both ACC proper width, lumen $5.9 \mathrm{~mm}$, VPS $270 \mathrm{~cm} / \mathrm{s}$ Ved $58 \mathrm{~cm} / \mathrm{s}$ turbulent flow. $1.5 \mathrm{~mm}$ with established atheroplaque diffuse stenosis ACC both sides as well as the initial segments of the ACI. ACI Left stenosis of about $80 \%$, right around $70 \%$. Also with diffuse gentle atheroplaque. ACC right VPS $215 \mathrm{~cm} / \mathrm{s}$ Ved $26 \mathrm{~cm} / \mathrm{s}$, AVD diameter of $3.0 \mathrm{~mm}$, VPS $72 \mathrm{~cm} / \mathrm{s}$ Ved $28 \mathrm{~cm} / \mathrm{s}$, AVS diameter of $2.6 \mathrm{~mm}$, VPS $54 \mathrm{c} / \mathrm{s}$ Ved $21 \mathrm{~cm} / \mathrm{s}$. It is the expressed atherosclerotic changes diffused with turbulent flow and mutual stenosis above as well as the initial segments of ACI. On the right art.verthebralis accelerated flow as a result of extravassal compression, the left retrograde flow (steal phenomenon) with stenosis of the left subclavian artery. Neurological examination: Status post ICV per emboliam/lacunaris/am III, dysphasia sensomotoria bene sanata. The patient conscious, oriented, communicative, mobile, eyeball normal conjugated moving, without nystagmus and double vision, face no asymmetry, the extremity without lateralization, MTR moderate symmetrical, GMS preserved, Babinski reflex mutually negative, in the Romberg discreetly slaughtered (Therapy: Aspirin 150mg tablets 1x1, 1x1 Plavix 75mg tablets).

\section{Cardiac Examination}

ECG sinus rhythm fr $=73 / \mathrm{min}$, the PQ $0.14, \mathrm{HLV}, \mathrm{EF}=44-46 \%$, RR on the right hand of $200 / 80 \mathrm{mmHg}$ and $160 / 80 \mathrm{mmHg}$ of the left 
Citation: Fazlić A, Zuko M, Sokić-Begović E, Šuškić S, Šuškić A (2019) Reconstruction of Internal Carotid Artery Stenosis in Patients Older than 70 Years under Local Anaesthesia. J Anesth Clin Care 6: 44.

hand with the diagnosis Cor artheroskleroticum compesatum (in the therapy used: Lanibos $0.125 \mathrm{mg}$ tablets $1 \times 1$-no weekends, Lopril-H and $5 \mathrm{mg} 0+0+1 / 2$ tablets, Aldactone $25 \mathrm{mg}$ tablets $1 \times 1$, NTGR and $2.5 \mathrm{mg} 1+1+0$ caps, and Controloc $40 \mathrm{mg} 1 / 2+0+0$ tbl.). Pulmonary examination has shown: Status post Insuf.pulmonum hypoventilation acuta aa II; status post effusio cavi pleaurae bill I aa; Status post Bronchopneumonia bill. am X; (Therapy: Onbrez inhalation 2x1 breath, Alvesco $160 \mathrm{mg}$ inhalation $2 \times 1$ breath) increased airway resistance leads to the lake ventilatory insufficiency predominantly obstructive type. FEV1 Prev3:02, Act1 1.87, (\%A/P)61.9\%. prolonged expiratory with poliforne whistles, X-ray in PA projection: shadow hearts neat size, hilar differentiated, hemidiaphragm duly reduced, the lung parenchyma no pathological acute activitis and inflammation.

After preparation of the patient, it was decided that surgery will done under local anesthesia. Provide the arterial line (punctio right radial artery with 20 -gauge arterial chateter), i.v.canila $14 \mathrm{G}$, ECG, $\mathrm{SpO}_{2}$, spontaneously breathing with oxygen support to the mask, Mannitol $20 \% 250 \mathrm{ml}$, total liquid $0.9 \% \mathrm{NaCl} 750 \mathrm{ml}, 5000 \mathrm{IU}$ of Heparin. The initial blood pressure was $200 / 120 \mathrm{mmHg}$, fr $80 / \mathrm{min}$, $\mathrm{SpO} 2100 \%$. During surgery, the patient was, all time, conscious and communicative. Apply on Xilocain to achieve anesthetic action left carotid region. Access to the ACC, ACI and ACE left with facial vein ligation and preservation $n$. hypoglossus (Figures 1 and 2).
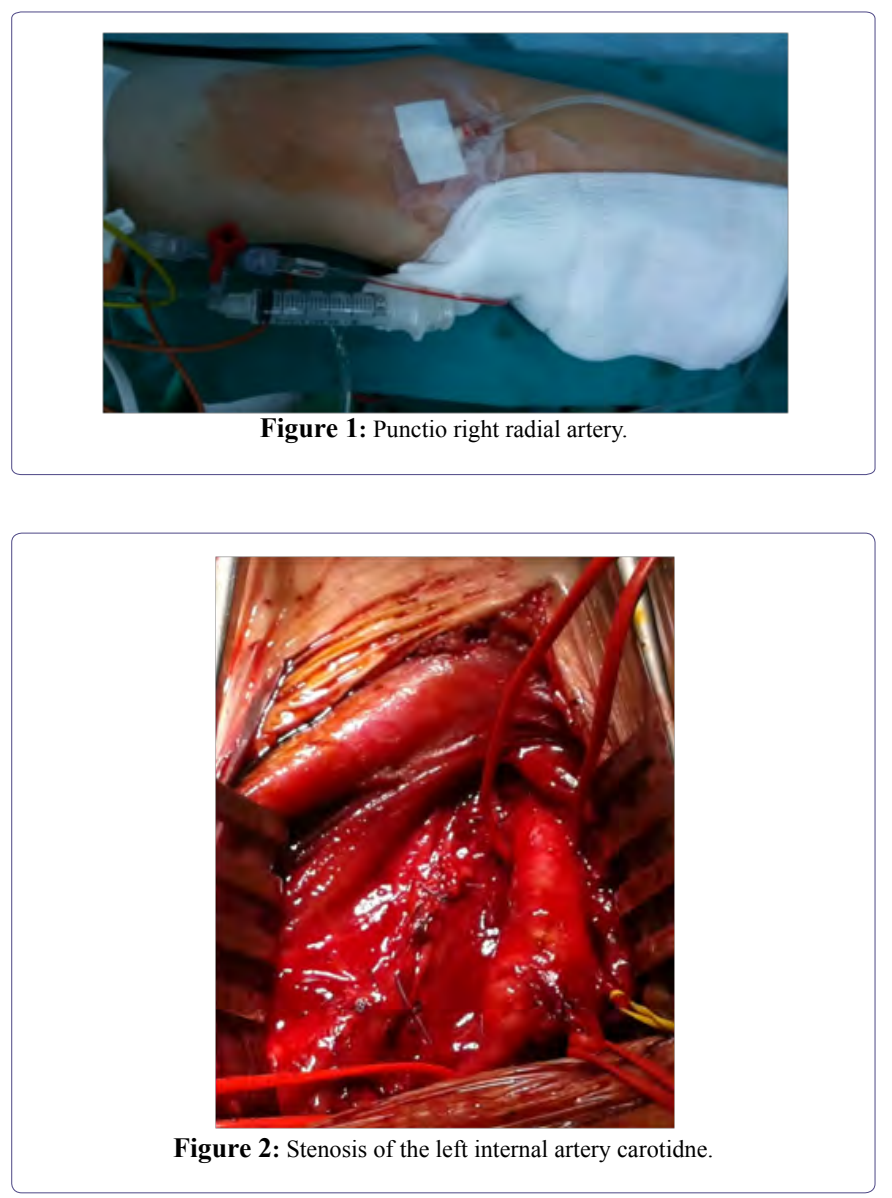

The taxidermist is difficult because of inflammatory changes in the individual layers of the left carotid region. Also recorded anatomical dislocation of nerve and vascular structures that hamper the preparations. During the operation there was no neurological disturbances. At one point, blood pressure rises up to $275 / 140 \mathrm{~mm} \mathrm{Hg}$, the patient was conscious, communicative, without any problems, answer all questions. Clamping mentioned artery endarterectomy everzion bifurcation and ACI and then TL anastomosis ACI on bifurcation ACC thread Prolene 5/0. Clamping time was $10 \mathrm{~min}$. Arterial pressure $170 / 110 \mathrm{mmHg}$. At the end of surgery, blood pressure was $130 / 52$ $\mathrm{mmHg}$ (Figures 3 and 4).
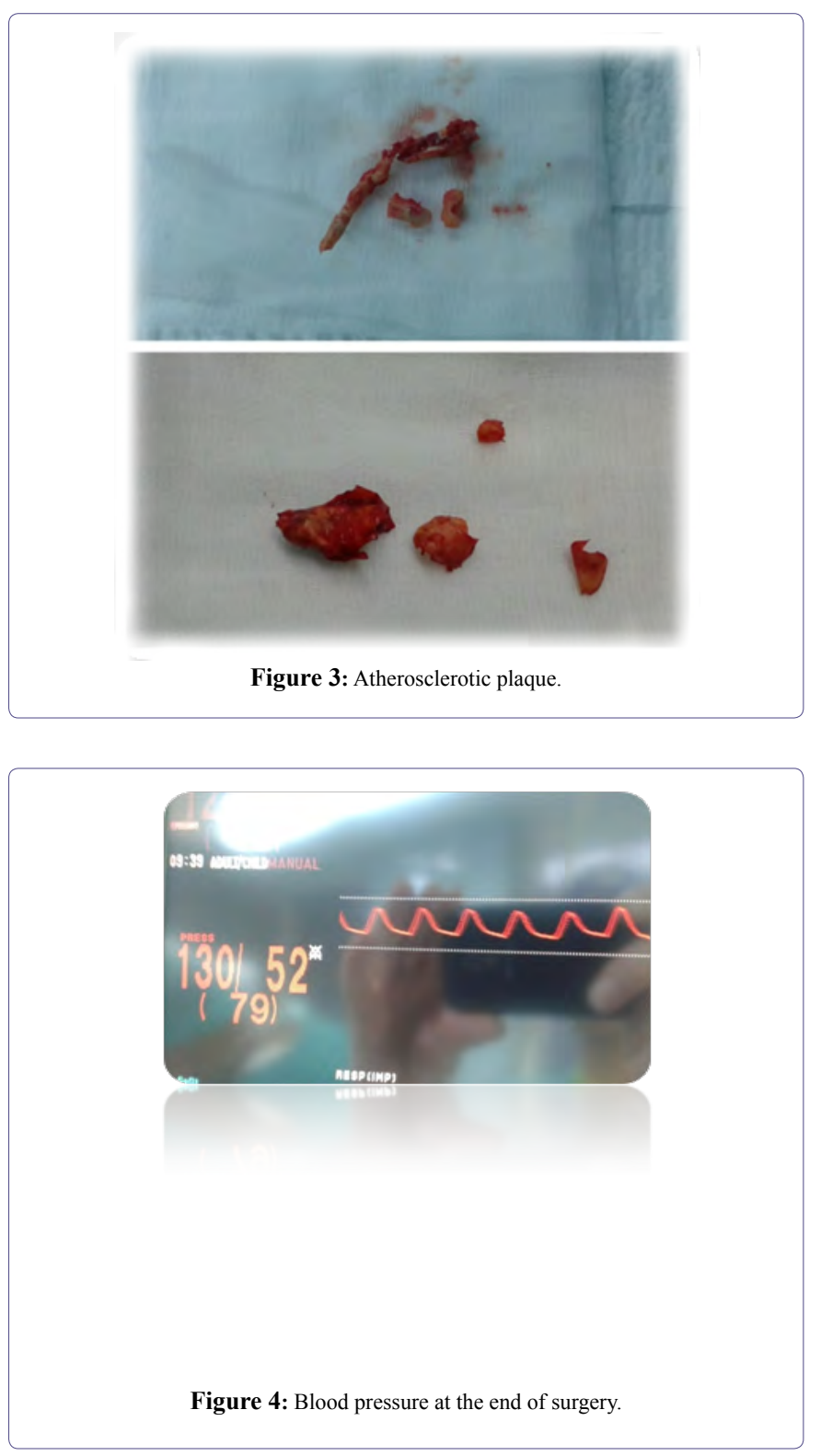

\section{Discussion}

Early diagnosis and treatment are of utmost importance for the patients. Sometimes, diagnosis can be challenging in patiazents without neurological symptoms, in particular. Radak et al., showed that $31,9 \%$ of cases are asymptomatic at the time diagnosis [5]. The first step in the diagnosis is Doppler ultrasound, which is a simple and 
noninvasive imaging modality. Also, artheriography is the gold standard for thrombus location and collateral circulation [6]. The primary indication for surgery is the prevention for permanent neurological damege from thromboembolic events [7]. However, a many patientsdo not have any simptoms and that resulted with stroke. Our patient, is recovering from a stroke, but the problem arises when you have the symptoms of inflammation of the gallbladder without solution of stenosis of the internal carotid artery. Having in mind that this is a surgery in which the required clamping the carotid artery, and that the most patients have advanced coronary disease, anesthesia must be balanced so that: prevent drastic hemodynamic disturbances on the introduction of anesthesia during the operation, as well as during waking and extubation, and the provide patient wakefulness at the end of the operation and the ability to carry out controls during neurological assessment [8]. Seeing the general situation of our patients, we decided to use a local anesthetic that has proven safety for our patient.

\section{References}

1. Jukić M, Husedžinović I, Kogler VM, Perić M, Žunić J, et al. (2013) Klinička anesteziologija. Medicinska Naklada, Serbia, Balkans. Pg no: 1180 .
2. Europien Registers of Stroke (EROS) Investigators, Heuschmann PU, Di Carlo A, Bejot Y, Rastenyte D, et al. (2009) Incidence of stroke in Europe at the beginning of the 21 st century. Stroke 40: 1557-1563.

3. Larsen R (2012) Anästhesie und Intensivmedizin in der Herz-,Thorax- und Gefäßchirurgie. 8 Auflage: Springer-Verlag Berlin Heidelberg, Berlin, New York, USA.

4. Rothwell PM, Eliasziw M, Gutnikov SA, Fox AJ, Taylor DW, et al. (2003) Analysis of pooled data from the randomised controlled trials of endarterectomy for symptomatic carotid stenosis. Lancet 361: 107-116.

5. Radak D, Davidović L, Vukobratov V, Ilijevski N, Kostić D, et al. (2007) Carotid artery aneurysms: Serbian multicentric study. Ann Vasc Surg 21: 23-29.

6. Windfuhr JP (2001) Aneurysm of the internal carotid artery following soft tissue penetration injury. Int J Pediatr Otorhinolaryngol 61: 155-159.

7. Szopinski P, Ciostek P, Kielar M, Myrcha P, Pleban E, et al. (2005) A series of 15 patients with extracranial carotid artery aneurysms: surgical and endovascular treatment. Eur J Vasc Endovasc Surg 29: 256-261.

8. Millers RD, Eriksson LI, Fleisher LA, Wiener-Kronish J, Young W (2009) Miller's Anesthesia (7thedn). Churchill Livingstone, London, United Kingdom. 


\section{II}

Journal of Anesthesia \& Clinical Care

Journal of Addiction \& Addictive Disorders

Advances in Microbiology Research

Advances in Industrial Biotechnology

Journal of Agronomy \& Agricultural Science

Journal of AIDS Clinical Research \& STDs

Journal of Alcoholism, Drug Abuse \& Substance Dependence

Journal of Allergy Disorders \& Therapy

Journal of Alternative, Complementary \& Integrative Medicine

Journal of Alzheimer's \& Neurodegenerative Diseases

Journal of Angiology \& Vascular Surgery

Journal of Animal Research \& Veterinary Science

Archives of Zoological Studies

Archives of Urology

Journal of Atmospheric \& Earth-Sciences

Journal of Aquaculture \& Fisheries

Journal of Biotech Research \& Biochemistry

Journal of Brain \& Neuroscience Research

Journal of Cancer Biology \& Treatment

Journal of Cardiology: Study \& Research

Journal of Cell Biology \& Cell Metabolism

Journal of Clinical Dermatology \& Therapy

Journal of Clinical Immunology \& Immunotherapy

Journal of Clinical Studies \& Medical Case Reports

Journal of Community Medicine \& Public Health Care

Current Trends: Medical \& Biological Engineering

Journal of Cytology \& Tissue Biology

Journal of Dentistry: Oral Health \& Cosmesis

Journal of Diabetes \& Metabolic Disorders

Journal of Dairy Research \& Technology

Journal of Emergency Medicine Trauma \& Surgical Care

Journal of Environmental Science: Current Research

Journal of Food Science \& Nutrition

Journal of Forensic, Legal \& Investigative Sciences

Journal of Gastroenterology \& Hepatology Research

Journal of Gerontology \& Geriatric Medicine
Journal of Genetics \& Genomic Sciences

Journal of Hematology, Blood Transfusion \& Disorders

Journal of Human Endocrinology

Journal of Hospice \& Palliative Medical Care

Journal of Internal Medicine \& Primary Healthcare

Journal of Infectious \& Non Infectious Diseases

Journal of Light \& Laser: Current Trends

Journal of Modern Chemical Sciences

Journal of Medicine: Study \& Research

Journal of Nanotechnology: Nanomedicine \& Nanobiotechnology

Journal of Neonatology \& Clinical Pediatrics

Journal of Nephrology \& Renal Therapy

Journal of Non Invasive Vascular Investigation

Journal of Nuclear Medicine, Radiology \& Radiation Therapy

Journal of Obesity \& Weight Loss

Journal of Orthopedic Research \& Physiotherapy

Journal of Otolaryngology, Head \& Neck Surgery

Journal of Protein Research \& Bioinformatics

Journal of Pathology Clinical \& Medical Research

Journal of Pharmacology, Pharmaceutics \& Pharmacovigilance

Journal of Physical Medicine, Rehabilitation \& Disabilities

Journal of Plant Science: Current Research

Journal of Psychiatry, Depression \& Anxiety

Journal of Pulmonary Medicine \& Respiratory Research

Journal of Practical \& Professional Nursing

Journal of Reproductive Medicine, Gynaecology \& Obstetrics

Journal of Stem Cells Research, Development \& Therapy

Journal of Surgery: Current Trends \& Innovations

Journal of Toxicology: Current Research

Journal of Translational Science and Research

Trends in Anatomy \& Physiology

Journal of Vaccines Research \& Vaccination

Journal of Virology \& Antivirals

Archives of Surgery and Surgical Education

Sports Medicine and Injury Care Journal

International Journal of Case Reports and Therapeutic Studies

Journal of Ecology Research and Conservation Biology

Submit Your Manuscript: http://www.heraldopenaccess.us/Online-Submission.php 